Review Article

\title{
Impact of Using Brilliant Cresyl Blue Stain on Oocyte and Embryo Selection
}

\author{
Al-Shimaa A. Hasb El-Naby*, Karima Gh.M .Mahmoud**, M. El-Raey*, Y.F. \\ Ahmed**, M.E.A. Abouel-Roos* and Gamal A.M. Sosa* \\ *Department of Theriogenology, Faculty of Veterinary Medicine, Benha University \\ and**Department of Animal Reproduction and A.I., National Research Centre, Cairo, \\ Egypt.
}

\begin{abstract}
$\mathbf{T}$ HE SUCCESS of in vitro embryo production is ultimately dependent on the number and quality of cumulus-oocyte complexes harvested from ovaries. The morphological criteria are routinely used for oocytes selection in most laboratories. There is brilliant cresyl blue stain (BCB) test allowing the selection of developmentally competent oocytes which is a simple, quick, economic and feasible protocol. $\mathrm{BCB}$ is known to be a non-invasive methodology that allows the selection of immature oocytes in several species. BCB test determine the intra cellular activity of glucose-6-phosphate dehydrogenase (G6PDH) that gradually decreases its activity as oocytes reach their growth phase. The using of $\mathrm{BCB}$ test before IVM is still controversial, so this review describes the use of $\mathrm{BCB}$ staining test for oocytes and embryo selection to investigate the impact of application of this stain in in-vitro maturation and embryo production in animals.
\end{abstract}

Key words: Oocytes quality, brilliant cresyl blue stain, embryo quality, selection, in vitro maturation.

\section{Introduction}

The in vitro production (IVP) inefficiency of embryos has been related to oocyte quality at the start of maturation [1]. The identification and selection of oocytes with good developmental competence is a critical step for successful embryo technologies [2]. Many reports used brilliant cresyl blue (BCB) staining test as an efficient method to screen and classify oocytes quality for various species as buffalo and ovine $[3,4]$.

Quality of oocytes that developed into viable embryos was still an issue of major interest in assisted reproduction technologies [5]. It was known that good quality oocytes were associated with better maturation rate in vitro. The optimal oocyte developmental potential required synchronization between nuclear and cytoplasmic maturation [6]. Cytoplasmic maturation involved a complex molecular reactions as protein phosphorylation, biological macromolecule synthesis and activation of certain metabolic pathways [7].
Rizos et al. [8] mentioned that the intrinsic oocyte quality determined the blastocyst yield, while post fertilization culture system determined the blastocyst quality. Routinely, oocyte quality determinations depended on cytoplasm uniformity and the layer of cumulus cells [9].

\section{Oocyte quality and selection}

Oocyte selection in the laboratory was a key factor which determined the proportion of oocytes developing to blastocyst stage in animal species. Oocyte quality affected the ability of oocytes to mature, fertilize, give early embryonic survival, maintenance of pregnancy, fetal development and normal offspring $[10,11]$.

Morphological factors related to the quality of cumulus oocyte complexes (COC) and /or oocytes include COC morphology, number of cumulus cell layers [12], oocyte diameter [13] and oocyte coloration [14].In addition, the size of perivitelline space [15], thickness, organization of zona pellucida [16], mitochondrial distribution 
and glucose-6-phosphate dehydrogenase activity measured by BCB staining of immature oocytes $[17,18]$.

There were various factors appeared to be critical to oocyte quality including age of donor animal [19,20], maturation media [21], phase of follicular wave [22], follicular size [23], follicle health [24], environmental factors as season or heat stress [25,26,27], hormonal stimulation [28], nutrition [29], storage temperature [30], lactation status of donor animal [31] and genetic background [32,33].

There was a relationship between oocyte size, follicular diameter and its competence [34]. Follicular size affected oocyte quality, which implicating messenger RNA or protein stores as factors involved in oocyte competence [35]. Crozet et al. [36] observed a higher blastocysts percent $(6 \%, 12 \%, 26 \%)$ using oocytes from small (2-3 mm), medium (3-5 mm), large $(>5$ $\mathrm{mm})$ follicles, respectively. The efficiency of in vitro techniques was low for prepubertal animals as oocyte donors. Prepubertal oocytes were characterized by abnormal cytoplasmic maturation and lower ability to achieve blastocyst stage than those coming from adult donors [37].

Also, Martino et al. [38] mentioned that the ovaries of prepubertal animals had a higher proportion of antral follicles with a diameter smaller than $3 \mathrm{~mm}$ and was difficult to release the cumulus oocyte complexes (COCs) by aspiration method. For this reason, oocytes were obtained by slicing the ovary surface, resulting oocytes with different diameters and heterogeneous morphology. In prepubertal goat and sheep, Anguita et al. [39], Catala et al. [40] stated that oocytes with a diameter larger than $125 \mu \mathrm{m}$ produced higher percentages of blastocyst after IVF. Thus oocyte diameter was a determinant factor for completion of meiosis and full competence for embryo development.

Communication between oocyte and its surrounding cumulus cells was also important for the development of competent oocyte at ovulation. Moor and Dai[41]stated that pig oocytes depended on the presence of follicle cells to generate specific cellular signals that coordinate oocyte growth and maturation.

Metabolism might play a critical role in oocyte quality because glycolytic activity in mature oocytes was related with increased embryonic development. Oocytes matured in vitro often Egypt. J. Vet. Sci. Vol. 48, No.1 (2017) had altered energy metabolism lead to reduced developmental potential. This might reflect a deficiency in maturation medium or its intrinsic ability or both [42].

\section{Embryo quality}

Embryo quality is an important determinant for successful practical embryo transfer to improve the pregnancy rates. Blastocyst development was the main step for production of live offspring [43]. Comparing the in vivo and in vitro counter parts produced embryos, in vitro produced embryos tend to have darker cytoplasm and lower density [44] as a consequence of their higher lipid content [45], more fragile zona pellucid [46], reduced expression of inter cellular communication devices [47], differences in metabolism [48] and a higher incidence of a chromosomal abnormalities [49].

Several methods for embryo evaluation had been developed as measurement of enzyme activity [50], glucose uptake [51], live-dead stains [52] and morphological evaluations [53]. Two parameters commonly used to evaluate embryo quality include non-invasive and invasive method. The non-invasive method involved embryo color, shape, number, compactness of cells, size of perivitelline space, and number of degenerated cells $[53,54]$. While, the invasive techniques involved total cell number determination by nucleus staining using propidium iodide (PI) or Hoechst stain [55], evaluation the inner cell mass (ICM) differentiation, trophectoderm (TE) by differential staining [56], cryotolerance [57] and detection of apoptotic cells using different staining techniques [58].

Using of brilliant cresyl blue stain in oocytes and embryos selection

Many reports used brilliant cresyl blue staining as a vital stain to detect the quality oocytes in various species such as buffaloes $[3,59,60]$, sheep [61], cattle $[62,17,18,63]$, pig $[64,65]$, prepubertal goat $[66,67,68]$, dog [69] and mice [70]. But, the using of this test for embryo selection still remains an open issue.

It was known that immature oocytes synthesized several proteins, including glucose6-phosphate dehydrogenase during their growth course [71]. Ericsson et al. [72] suggested a simple test for the selection of porcine oocytes which had good developmental competence depending on measurement of glucose-6phosphate dehydrogenase (G6PDH) activity. 
A function of G6PDH enzyme was to produce ribose sugars for nucleic acids synthesis through the pentose shunt [17]. Another important function of G6PDH enzyme was responsible for production of NADPH for lipid synthesis [73]. The G6PDH enzyme converted the dye into a colorless form. Oocytes which stained blue (BCB+, low G6PDH activity) were distinguished by higher developmental competence (good quality), while the colorless oocytes $\left(\mathrm{BCB}^{-}\right.$, high activity of G6PDH) were characterized by low developmental competence (low quality) [72].

There was species-specific frequency to the response of different concentration of BCB. Many studies reported that the rate of maturation, cleavage and development into blastocyst of selected oocytes, using $26 \mu \mathrm{M} \mathrm{BCB}$ were higher than in oocytes selected with $13 \mu \mathrm{M}, 39 \mu \mathrm{M}$ and $52 \mu \mathrm{M}$ BCB in different species as in buffalo [3], goat [68], cattle [17,73], mice [74], sheep [4,75] and bitch [69].

The proportion of $\mathrm{BCB}+: \mathrm{BCB}^{-}$oocytes were related to the species specific frequency of positive coloration of oocyte before oocyte maturation process [2]. In cattle and buffalo, $\mathrm{BCB}+\mathrm{BCB}^{-}$ oocyte was $60: 40[17,18,3]$, in prepubertal goat was $30: 70[76]$ and in pig was $84: 16$ [77].

BCB staining was not only used for oocytes, but also used for zygote treatment. Mirshamsi et al. [78] stained bovine zygote by $\mathrm{BCB}$ for 10 min after maturation and fertilization in vitro. They categorized the zygote into three classes, high stained (ZBCB++: low competent zygotes), moderate stained $(\mathrm{ZBCB}+$ : moderate competent zygotes) and unstained ( $\mathrm{ZBCB}^{-}$: more competent zygotes). The same authors added that selection of oocyte and zygote by BCB test improved the selecting efficiency of high quality embryos, compared to single $\mathrm{BCB}$ test.

\section{Advantage of using $B C B$}

Egerszegi et al. [2] stated that $\mathrm{BCB}+$ porcine oocytes at the beginning of IVM were characterized by high mitochondrial activity in their cytoplasm, the activity was decreased after $22 \mathrm{~h}$ of IVM, stayed at the same level up to the final maturation, while $\mathrm{BCB}^{-}$oocytes population during IVM had a low level of mitochondrial activity without dynamic changes. Moreover, its activity increased at fertilization and early embryonic development as their respiratory activities were positive related with meiotic progress and cumulus cell expansion rate [79].
It was reported that G6PDH activity not only related to cytoplasmic maturation and mitochondrial activity [80], but also related to cytoplasmic lipid content [81]. Castaneda et al. [82] demonstrated that the higher lipid content of $\mathrm{BCB}+$ bovine oocytes provided a functional and cellular basis for their greater developmental competence. Cytoplasmic lipid content had been described recently as an essential parameter for oocyte developmental competence and early embryo development in cattle [83] and sheep [75].

In sheep, BCB stain was effective method for oocyte selection and verified this through the relation between stained oocytes, oocyte diameter, GSH content and developmental competence. The diameter of $\mathrm{BCB}+$ oocytes was $163 \mu \mathrm{m}$, while the diameter of $\mathrm{BCB}^{-}$oocytes was $159 \mu \mathrm{m}$. Glutathione content in $\mathrm{BCB}+$ was $6.39 \mathrm{pM}$, while GSH content in $\mathrm{BCB}^{-}$was $0.26 \mathrm{pM}[61]$.

Opiela et al. [84] suggested that the advantage of BCB staining included; picking out of oocytes with better developed mitochondria, higher cleavage and blastocyst number for $\mathrm{BCB}+$ stained oocytes, compared to $\mathrm{BCB}^{-}$oocytes. But, its hardship included lack of significant difference between blastocyst numbers from $\mathrm{BCB}+$ and control oocytes. Also, extension of the overall time for oocyte recovery since the BCB test required extra manipulation and handling. This time requirement would also result in increased cost which affected on overall IVP efficiency [85]. In cases where careful morphological selection was conducted before subjecting oocytes to BCB staining, only $30 \%$ of COCs remained colorless. This was the most likely cause of the lack of statistical differences between blastocysts developed from $\mathrm{BCB}+$ and control oocytes [84]. Moreover, there was no report proved that blastocyst rates obtained from $\mathrm{BCB}+$ oocytes higher than routine IVP with morphologically selected oocytes by $30-40 \%$ [86].

\section{Disadvantage of using $B C B$}

Scholkamy et al. [87] reported a higher DNA damage in both $\mathrm{BCB}+$ and $\mathrm{BCB}-$ oocytes, compared to non-stained control vitrified oocytes. Also, Pawlak et al. [88] observed a higher rate of chromosomal abnormalities in porcine oocytes when stained by BCB. Wongsrikeao et al. [89] concluded that $\mathrm{BCB}$ staining after in vitro maturation had a negative impact on the cleavage and development of porcine embryos. Opiela et al. [84] indicated that oocytes subjected to BCB 
staining had a tendency towards apoptosis as the Bax transcript level in BCB- oocytes was significantly higher $(\mathrm{P}<0.001)$ in comparison to non-stained oocytes. In addition, Pawlak et al. [90] do not recommend the application of BCB staining in oocyte selection due to relatively high similarity in in-vitro maturation of $\mathrm{BCB}+$ and control oocytes.

\section{Conclusion}

Oocyte selection was a vital step for successful in vitro embryo production process. Many reports were used brilliant cresyl blue stain for oocyte selection. But, recent studies do not recommend to use this stain as a routine work for oocyte selection as it is chemical toxic substance, time consuming and had deleterious effect on embryos.

\section{References}

1. Gasparrini, B. (2002) In vitro embryo production in buffalo species: State of the art. Theriogenol., 57, 237-256.

2. Egerszegi, I., Alm, H., Rátky, J., Heleil, B., Brüssow, K.P. and Torner, H. (2010) Meiotic progression, mitochondrial features and fertilization characteristics of porcine oocytes with different G6PDH activities. Reprod. Fertil. Dev., 22, 830-838.

3. Manjunatha, B.M., Gupta, P.S.P., Devaraj, M.,Ravindra, J.P. and Nandi, S. (2007) Selection of developmentally competent buffalo oocytes by brilliantcresyl blue staining before IVM. Theriogenol., 68, 1299-1304.

4. Wang, L., Lin, J., Huang, J., Wang, J., Zhao, Y. and Chen, T. (2012) Selection of ovine oocytes by brilliant cresyl blue staining. J. Biomed. Biotechnol., 1, 1- 7.

5. Ruvolo, G., Fattouh, R.R., Bosco, L.,Brucculeri, A.M. and Cittadini, E. (2013) New molecular markers for the evaluation of gamete quality.J. Assist. Reprod. Genet., 30 (2), 207-212.

6. Mattioli, M., Bacci, M.L.,Galeati, G. and Seren, E. (1991) Effects of LH and FSH on the maturation of pig oocytes in vitro.Theriogenol.,36, 95-105.

7. Luberda, Z. (2005) The role of glutathione in mammalian gametes. Reprod. Biol.,5, 5-17.

8. Rizos, D., Ward, F., Duffy, P., Boland, M.P. and Lonergan, P. (2002) Consequences of bovine oocyte maturation, fertilization or early embryo development in vitro versus in vivo: Implications for blastocyst yield and blastocyst quality.Mol. Reprod. Dev., 61, 234-248.

Egypt. J. Vet. Sci. Vol. 48, No.1 (2017)
9. Gordon, I. (2003) Laboratory production of cattle embryos: Maturing the oocyte, 2th edition, Cambridge, MA 02138, CABI publishing.

10. Duranthon, V. and Renard, J.P. (2001)The developmental competence of mammalian oocytes: A convenient but biologically fuzzy concept. Theriogenol., 55 (6), 1277-1289.

11. Krisher, R.L. (2004)The effect of oocyte quality on development. J. Anim. Sci., 82, 14-23.

12. Yuan, Y.Q., Van Soom, A., Leroy, J.L., Dewulf, J., Van Zeveren, A., de Kruif, A., Peelman, L.J. (2005) Apoptosis in cumulus cells, but not in oocytes, may influence bovine embryonic developmental competence. Theriogenol., 63, 2147-2163.

13. Fair, T. (2003) Follicular oocyte growth and acquisition of developmental competence. Anim. Reprod. Sci., 78, 203-216.

14. Nagano, M., Katagiri, S., Takahashi, Y. (2006) Relationship between bovine oocyte morphology and in vitro developmental potential. Zygote, 14, 53-61.

15. De Sutter, P., Dozortsev, D., Qian, C. and Dhont, M. (1996) Oocyte morphology does not correlate with fertilization rate and embryo quality after intra-cytoplasmic sperm injection. Hum. Reprod., 11, 595-597.

16. Gabrielsen, A.,Lindenberg, S. and Petersen, K. (2001) The impact of the zonapellucida thickness variation of human embryos on pregnancy outcome in relation to suboptimal embryo development. A prospective randomized controlled study.Hum. Reprod., 16, 2166-2170.

17. Alm, H., Torner, H., Lochrke, B., Viergutz, T., Ghoneim, I.M. and Kanitz, W. (2005) Bovine blastocyst development rate in vitro is influenced by selection of oocytes by brilliant cresyl blue staining before IVM as indicator for glucose-6phosphate dehydrogenase activity. Theriogenol., 63, 2194-2205.

18. Bhojwani, S., Alm, H., Torner, H.,Kanitz, W. and Poehland, R. (2007) Selection of developmentally competent oocytes through brilliant cresyl blue stain enhances blastocyst development rate after bovine nuclear transfer. Theriogenol., 67, 341-345.

19. Esteves, T.C.,Balbach, S.T., Pfeiffer, M.J., ArauzoBravo, M.J., Klein, D.C., Sinn, M. and Boiani, M. (2011) Somatic cell nuclear reprogramming of mouse oocytes endures beyond reproductive decline. Aging Cell, 10, 80-95. 
20. Batista, E.O., Guerreiro, B.M.,Freitas, B.G., Silva, J.C., Vieira, L.M., Ferreira, R.M., Rezende, R.G., Basso, A.C., Lopes, R.N., Rennó, F.P., Souza, A.H. and Baruselli, P.S. (2016) Plasma anti-Müllerian hormone as a predictive endocrine marker to select Bostaurus (Holstein) and Bos indicus (Nelore) calves for in vitro embryo production. Domest. Anim. Endocrinol., 54, 1-9.

21.Warzych, E., Peippo, J.,Szydlowski, M. and Lechniak, D. (2007) Supplements to in vitro maturation media affect the production of bovine blastocysts and their apoptotic index but not the proportions of matured and apoptotic oocytes. Anim. Reprod. Sci., 97, 334-343.

22. Machatkova, M., Krausova, K.,Jokesova, E. and Tomanek, M. (2004) Developmental competence of bovine oocytes: Effects of follicle size and the phase of follicular wave on in vitro embryo production.Theriogenol., 61, 329-335.

23. Lonargan, P., Monghan, P., Rizoz, D., Boland, M.P. and Gordon, I. (1994) Effect of follicle size on bovine oocyte quality and developmental competence following maturation, fertilization and culture in vitro.Mol. Reprod.and Dev., 37, 48-53.

24. Vassena, R., Mapletoft, R.J., Allodi, S., Singh, J. and Adams, G.P. (2003) Morphology and developmental competence of bovine oocytes relative to follicular status.Theriogenol.,60, 923-932.

25. Zoheir, K.M.A., Abdoon, A.S., Mahrous, K.F., Amer, M.A., Zaher, M.M., Yang, L. and ElNahass, E.M. (2007) Effects of season on the quality and in vitro maturation rate of Egyptian buffalo (Bubalus bubalis) oocytes. J. Cell Anim. Biol., 1 (2), 029-033.

26. El-Naby, Al-Shaimaa A.H., Mahmoud, K.Gh.M., Ahmed, Y.F., Abouel-Roos, M.E.A. and AbdelGhaffar, A.E. (2013) Effect of season of the year and ovarian structures on oocytes recovery rate, quality and meiotic competence in Egyptian buffaloes. Global Vet., 10 (4), 408-412.

27. Ferreira, R.M., Chiaratti, M.R., Macabelli, C.H., Rodrigues, C.A., Ferraz, M.L., Watanabe, Y.F., Smith, L.C., Meirelles, F.V.,Baruselli, P.S. (2016) The infertility of repeat-breeder cows during summer is associated with decreased mitochondrial DNA and increased expression of mitochondrial and apoptotic genes inoocytes. Biol. Reprod., 94 (3), 66.

28. Blondin, P., Bousquet, D., Twagiramungu, H., Barnes, F. and Sirard, M.A. (2002) Manipulation of follicular development to produce developmentally competent bovine oocytes. Biol. Reprod., 66, 38-43.
29. Fouladi-Nashta, A.A., Gutierrez, C.G., Gong, J.G.,Garnsworthy, P.C. and Webb, R. (2007) Impact of dietary fatty acids on oocyte quality and development in lactating dairy cows. Biol. of Reprod.,77, 9-17.

30. Wang, Y.S., Zhao, X., Su, J.M., An, Z.X., Xiong, X.R., Wang, L.J., Liu, J., Quan, F.S.,Hua, S. and Zhang, Y. (2011) Lowering storage temperature during ovary transport is beneficial to the developmental competence of bovine oocytes used for somatic cell nuclear transfer. Anim.Reprod. Sci., 124, 48-54.

31. Baruselli, P.S., Batista, E.O.S., Vieira, L.M., Ferreira, R.M., Guerreiro, B.G., Bayeux, B.M., Sales, J.N.S., Souza, A.H., Gimenes, L.U. (2016) Factors that interfere with oocyte quality for in vitro production of cattle embryos: Effects of different developmental and reproductive stages. Anim. Reprod., 13 (3), 264-272.

32. Gimenes, L.U., Ferraz, M.L., Fantinato-Neto, P., Chiaratti, M.R., Mesquita, L.G., SáFilho, M.F.,Meirelles, F.V., Trinca, L.A., Rennó, F.P., Watanabe, Y.F., Baruselli, P.S. (2015) The interval between the emergence of pharmacologically synchronized ovarian follicular waves and ovum pickup does not significantly affect in vitro embryo production in Bos indicus, Bos taurus, and Bubalus bubalis.Theriogenol., 83, 385-393.

33. Sales, J.N., Iguma, L.T., Batista, R.I., Quintão, C.C., Gama, M.A., Freitas, C., Pereira, M.M., Camargo, L.S., Viana, J.H., Souza, J.C.,Baruselli, P.S.(2015) Effects of a high energy diet on oocyte quality and in vitro embryo production in Bos indicus and Bos taurus cows. J. Dairy Sci., 98, 3086-3099.

34. Ledda, S., Bogliolo, L.,Leoni, G. and Naitana, S. (1999) Follicular size affects meiotic competence of in vitro matured prepubertal and adult oocytes in sheep. Reprod. Nutr. Dev., 39, 503-508.

35. Marchal, R., Vigneron, C.,Perreau, C., Bali-Papp, A. and Mermillod, P.(2002) Effect of follicular size on meiotic and developmental competence of porcine oocytes.Theriogenol., 57, 1523-1532.

36. Crozet, N., Dahirel, M. and Gall, L. (2000) Meiotic competence of in vitro grown goat oocytes. $J$. Reprod.Fertil.,118, 367-373.

37. Armstrong, D.T. (2001) Effects of maternal age on oocyte developmental competence. Theriogenol., 55, 1303-1322.

38. Martino, A.,Mogas, T., Palomo, M.J. and Paramio, M.T. (1994) Meiotic competence of prepubertal goat oocytes.Theriogenol., 41 (4), 969-980. 
39. Anguita, B., Jimenez-Macedo, A.R., Izquierdo, D.,Mogas, T. and Paramio, M.T. (2007) Effect of oocyte diameter on meiotic competence, embryo development, p34 (cdc2) expression and MPF activity in prepubertal goat oocytes. Theriogenol., 67, 526-536.

40. Catala, M.G., Izquierdo, D., Uzbekova, S., Morato', R., Roura, M., Romaguera, R.,Papillier, P. and Paramio, M.T. (2011) Brilliant cresyl blue stain selects largest oocytes with highest mitochondrial activity, maturation-promoting factor activity and embryo developmental competence in prepubertal sheep. Reprod., 142, 517-527.

41. Moor, R. and Dai, Y. (2001) Maturation of pig oocytes in vivo and in vitro. Reprod., 58, 91-104.

42. Gardner, D.K.,Pool, T.B. and Lane, M. (2000) Embryo nutritionand energy metabolism and its relationship to embryo growth, development and viability.Semin.Reprod. Med., 18, 205-218.

43. McEvoy T.G., Sinclair, K.D., Young, L.E., Wilmut, I. and Robinson, J.J. (2000) Large offspring syndrome and other consequences of ruminant embryo culture in vitro: Relevance to blastocyst culture in human ART. Hum. Fertil., 3, 238-246.

44. Pollard, J.W. and Leibo, S.P. (1994) Chilling sensitivity of mammalian embryos.Theriogenol., 41,101-107.

45. Abd El Razek, I.M., Charpigny, G., Kodja, S., Marquant-LeGuienne, B., Mermillod, P., GuyaderJoly, C. and Humblot, P. (2000) Differences in lipid composition between in vivo and in vitro produced bovine embryos. Theriogenol., 53, 346.

46. Duby, R.T., Hill, J.L., O’Callaghan, D., Overstrom, E.W. and Boland, M.P. (1997) Changes induced in the bovine zonapellucidaby ovine and bovine oviducts. Theriogenol., 47, 332.

47. Boni, R., Tosti, E., Roviello, S. and Dale, B. (1999) Intercellular communication in in-vivo-and in vitroproduced bovine embryos. Biol. of Reprod.,61, 1050-1055.

48. Thompson, J.G.(2000) In vitro culture and embryo metabolism of cattle and sheep embryos - a decade of achievement. Anim.Reprod. Sci.,60-61, 263-275.

49. Slimane, W., Heyman, Y. and Renard, J.P.(2000) Assessing chromosomal abnormalities by FISH analysis in 2-cell bovine embryos derived from in vitro and in vivo fertilization. Theriogenol., 53, 432.

Egypt. J. Vet. Sci. Vol. 48, No.1 (2017)
50. Schilling, E.,Smidt, D., Sacher, B., Petac, D. and ElKaschab, S. (1979) Diagnosis of the viability of earlybovine embryos by fluorescence microscopy. Ann. Biol.Anim. Biochem. Biophys., 19, 1625-1629.

51. Renard, J.P., Philippon, A. and Menezo, Y. (1980) In vitro uptake of glucose by bovine blastocysts.J. Reprod. Fertil., 58, 161-164.

52. Schilling, E., Niemann, H., Cheng, S.P. and Duepke, H.H. (1979) DAPI- a further fluorescence test for diagnosing the viability of early cow and rabbit embryos.Zuchthyg,14, 170-172.

53. Shea, B.F. (1981) Evaluating the bovine embryo. Theriogenol.,15, 13-42.

54. Merton, S. (2002) Morphological evaluation of embryos in domestic animals. In: VanSoom A. and Boerjan M. (Eds), Assessment of mammalian embryo quality: Invasive and non-invasive techniques. Dordrecht, The Netherlands: Kluwer Academic Publishers, 31-55.

55. Pursel, V.G., Wall, R.J., Rexroad, C.E., Hammer, R.E. and Brinster, R.L. (1985) A rapid wholemount staining procedure for nuclei of mammalian embryos.Theriogenol., 24, 687-700.

56. Van Soom, A.,Vanroose, G. and de Kruif, A. (2001) Blastocyst evaluation by means of differential staining: A practical approach. Reprod. Dom. Anim., 36, 29-35.

57. Shehab-El-Deen, M.A., Leroy, J.L.M.R., Maes, D. and Van Soom, A. (2009) Cryotolerance of bovine blastocysts is affected by oocyte maturation in media containing palmitic or stearic acid. Reprod. Dom. Anim., 44 (1), 140-142.

58. Wydooghe, E., Vandaele, L., Beek, J., Favoreel, H., Heindryckx, B., De Sutter, P. and Van Soom, A. (2011) Differential apoptotic staining of mammalian blastocysts based on double immunofluorescent CDX2 and active caspase-3 staining. Anal. Biochem., 416 (2), 228-230.

59. Mohapatra, S.K., Sandhu, A., Neerukattu, V.S., Singh, K.P., Selokar, N.L., Singla, S.K., Chauhan, M.S., Manik, R.S. and Palta, P. (2015) Buffalo embryos produced by handmade cloning from oocytes selected using brilliant cresyl blue staining have better developmental competence and quality and are closer to embryos produced by in vitro fertilization in terms of their epigenetic status and gene expression pattern. Cell Reprogram, 17 (2), $141-150$ 
60. El-Naby, Al.Al.H.H., Mahmoud, K.Gh.M., Ahmed, Y.F., Abouel-Roos, M.E.A. and Sosa, G.A.M. (2016) Effectiveness of using brilliant cresyl blue staining for quality evaluation and developmental competence of immature and mature buffalo oocytes. Global J. of Anim. Scientific Research, 4 (1), 20-26

61.Wang, L., Lin, J., Huang, J., Wang, J., Zhao, Y. and Chen, T. (2012) Selection of ovine oocytes by brilliant cresyl blue staining. J. Biomed. Biotechnol., 1, 1- 7 .

62. Pujol, M., Lopez-Bejar, M. and Paramio, M.T. (2004) Developmental competence of heifer oocytes selected using the brilliant cresyl blue (BCB) test. Theriogenol., 61,735-744.

63.Salviano, M.B., Collares, F.J., Becker, B.S., Rodrigues, B.A. and Rodrigues, J.L. (2015) Bovine non-competent oocytes (BCB-) negatively impact the capacity of competent $(\mathrm{BCB}+)$ oocytes to undergo in vitro maturation, fertilization and embryonic development. Zygote, 24 (2), 245-251.

64. El-Shourbagy, S.H., Spikings, E.C.,Freitas, M. and St John, J.C. (2006) Mitochondria directly influence fertilization outcome in the pig. Reprod., 131 (2), 233-245.

65. Fu, B., Ren, L., Liu, D., Ma, J.Z., An, T.Z., Yang, X.Q., Ma, H., Zhang, D.J., Guo, Z.H., Guo, Y.Y., Zhu, M. and Bai, J. (2015) Subcellular characterization of porcine oocytes with different glucose-6-phosphate dehydrogenase activities. Asian Australas. J. Anim. Sci., 28 (12), 1703-1712.

66. Rodriguez-Gonzalez, E., Lopez-Bejar, M., Velilla, E. and Paramio, M.T. (2002) Selection of prepubertal goat oocytes using the brilliant cresyl blue test. Theriogenol.,57, 1397-1409.

67. Urdaneta, A., Jimenez-Macedo, A.R.,Izquierdo, D. and Paramio, M.T. (2003) Supplementation with cysteamine during maturation and embryo culture on embryo development of prepubertal goat oocytes selected by the brilliant cresyl blue test. Zygote, 11, 347-354.

68. Abazari-Kia,A.H., Mohammadi-Sangcheshmeh, A., Dehghani Mohammadabadi, M., JamshidiAdegani, F., Veshkini, A., Zhandi, M.,Cinar, M.U. and Salehi, M. (2014) Intracellular glutathione content, developmental competence and expression of apoptosis-related genes associated with G6PDHactivity in goat oocyte. J. Assist. Reprod. Genet., 31, 313-321.
69. Rodrigues, B.A., Rodriguez, P., Silva, A.E., Cavalcante, L.F., Feltrin, C. and Rodrigues, J.L. (2009) Preliminary study in immature canine oocytes stained with brilliant cresyl blue and obtained from bitches with low and high progesterone serum profiles. Reprod. In Domest. Anim., 44, 2255-2258.

70. Salimi, M., Salehi, M., Farahani, R.M., Abadi, M.D.M., Novin, M.G.,Nourozian, M. and Hosseini, A. (2014) The effect of melatonin on maturation, glutathione level and expression of HMGB1 gene in brilliant cresyl blue (BCB) stained immature oocyte. Cell J., 15 (4), 294-301.

71. Wassarman, M. (1988) The mammalian ovum. In: The Physiology of Reproduction. Eds. Knobil E. and Neil j.D. Raven Press, New York., 1, 69-102.

72. Ericsson, S., Boice, M.,Funahashi, H. and Day, B. (1993) Assessment of porcine oocytes using brilliant cresyl blue. Theriogenol., 39 (1), 214.

73. Su, J., Wang, Y., Li, R., Peng, H., Hua, S., Li, Q., Quan, F., Guo, Z. and Zhang, Y. (2012) Oocytes selected using $\mathrm{BCB}$ staining enhance nuclear reprogramming and the in vivo development of SCNT embryos in cattle. PLoS One, 7 (4), e36181.

73. Wood, T. (1986) Physiological functions of the pentose phosphate pathway. Cell Biochem.Funct., 4 (4), 241-147.

74. Wu, Y.G., Liu, Y., Zhou, P., Lan, G.C., Han, D., Miao, D.Q. and Tan, J.H. (2007) Selection of oocytes for in vitro maturation by brilliant cresyl blue staining: A study using the mouse model. Cell Res., 17, 722-731.

75. Mohammadi-Sangcheshmeh, A., Veshkini, A., Hajarizadeh, A., Jamshidi-Adegani, F., Zhandi, M., Abazari-kia, A.H., Cinar, M.U.,Soleimani, M. and Gastal, E.L. (2014) Association of glucose-6-phosphate dehydrogenase activity with oocyte cytoplasmic lipid content, developmental competence, and expression of candidate genes in a sheep model. J. Assist. Reprod. Genet., 31, 1089 1098 .

76.Rodriguez-Gonzalez, E., Lopez-Bejar, M.,Izquierdo, D. and Paramio, M.T. (2003) Developmental competence of prepubertal goat oocytes selected with brilliant cresyl blue and matured with cysteamine supplementation. Reprod. Nut.Dev., 43 (2), 179-187. 
77. Wongsrikeao, P., Otoi, T., Yamasaki, H., Agung, B., Taniguchi, M., Naoi, H., Shimizu, R. and Nagai, T. (2006) Effects of single and double exposure to brilliant cresyl blue on the selection of porcine oocytes for in vitro production of embryos. Theriogenol., 66, 366-372.

78. Mirshamsi, S.M., Karamishabankareh, H., AhmadiHamedani, M., Soltani, L., Hajarian, H. and Abdolmohammadi, A.R. (2013) Combination of oocyte and zygote selection by brilliant cresyl blue (BCB) test enhanced prediction of developmental potential to the blastocyst in cattle. Anim. Reprod. Sci., 136 (4), 245-251.

79. Torner, H., Alm, H., Kanitz, W., Goellnitz, K., Becker, F., Poehland, R., Bruessow, K.P. and Tuchscherer, A. (2007) Effect of initial cumulus morphology on meiotic dynamic and status of mitochondria in horse oocytes during IVM. Reprod. Domest. Anim., 42, 176-183.

80. Jeong, W.J., Cho, S.J., Lee, H.S., Deb, G.K., Lee, Y.S., Kwon, T.H. and Kong, I.K. (2009) Effect of cytoplasmic lipid content on in vitro developmental efficiency of bovine IVP embryos.Theriogenol.,72 (4),584-589.

81. Hammami, S., Izquierdo, D., Catala, M.G., Paramio, M.T. and Morato, R. (2014) In vitro developmental competence of prepubertal goat oocytes cultured with recombinant activin-A. Anim.,8 (1), 94-101.

82. Castaneda, C.A., Kaye, P., Pantaleon, M., Phillips, N., Norman, S., Fry, R. and D'Occhio, M.J. (2013) Lipid content, active mitochondria and brilliant cresyl blue staining in bovine oocytes. Theriogenol.,79 (3), 417-422.

83. Ambruosi, B., Lacalandra, G.M., Iorga, A.I., De Santis, T., Mugnier, S., Matarrese, R.,Goudet, G. and Dell'aquila, M.E. (2009) Cytoplasmic lipid droplets and mitochondrial distribution in equine oocytes: Implications on oocyte maturation, fertilization and developmental competence after ICSI. Theriogenol., 71 (7), 1093-1104.

84. Opiela, J., Katska-Ksiazkiewicz, L., Lipiński, D., Słomski, R.,Bzowska, M. and Ryńska, B. (2008) Interactions among activity of glucose-6-phosphate dehydrogenase in immature oocytes, expression of apoptosis-related genes $\mathrm{BC}-2$ and $\mathrm{Bax}$, and developmental competence following IVP in cattle. Theriogenol., 69, 546-555.

Egypt. J. Vet. Sci. Vol. 48, No.1 (2017)
85. Katska-Ksiazkiewicz, L., Opiela, J. and Rynska, B. (2007) Effects of oocyte quality, semen donor and embryo co-culture system on the efficiency of blastocyst production in goats. Theriogenol., 68 , 736-744.

86. Vandaele, L. (2008) Intrinsic factors affecting apoptosis in bovine in vitro produced embryos. Ghent, Belgium: University of Ghent. Ph.D. Thesis, 109-123.

87. Scholkamy, T.H., Darwish, S.F. and Mahmoud, K.Gh.M. (2015) Effect of vitrification by straw and cryotop on DNA integrity using comet assay with reference to brilliant cresyl blue exposure in buffalo oocytes. Alex. J. of Vet. Sci., 46, 114-120.

88. Pawlak, P., Pers-Kamczyc, E., Renska, N., Kubickova, S., Lechniak, D. (2011) Disturbances of nuclear maturation in $\mathrm{BCB}$ positive oocytes collected from peri-pubertal gilts. Theriogenol., 75, 832-840.

89. Wongsrikeao, P., Otoi, T., Yamasaki, H., Agung, B., Taniguchi, M., Naoi, H., Shimizu, R., Nagai, T. (2006) Effects of single and double exposure to brilliant cresyl blue on the selection of oocytes for in vitro production of embryos. Theriogenol., 66, 366-372.

90. Pawlak, P., Warzych, E., Chabowska, A. and Lechnia, D. (2014) Differences in cytoplasmic maturation between the $\mathrm{BCB}+$ and control porcine oocytes do not justify application of the BCB test for a standard IVM protocol. Reprod Dev., 60 (1), $28-36$.

(Received 18/ 6/ 2017; accepted 13/8/2017) 


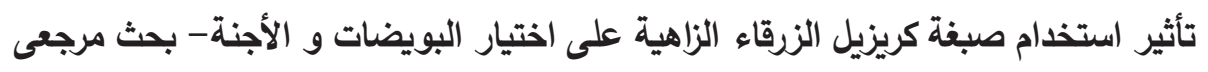

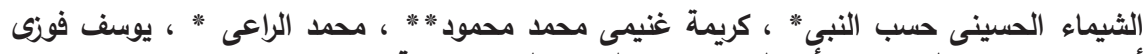

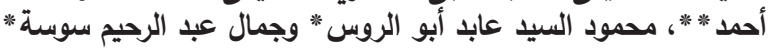

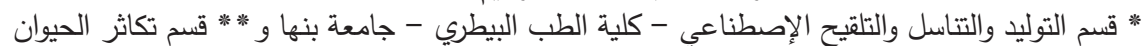

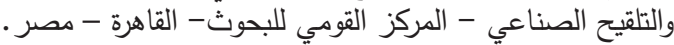

\begin{abstract}
يعتمد إنتاج الأجنة أساسا على عدد و جودة البويضات المجمعة من المبايض. و اختيار

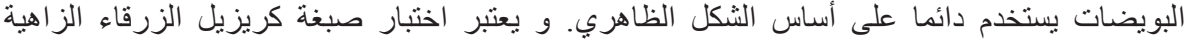

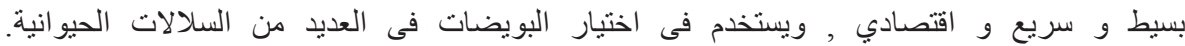

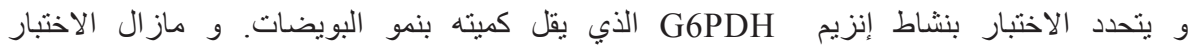

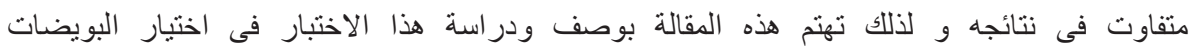
و الأجنة لمعرفة الددى و الجدوى من استخدامه فى النضج المعلي و إنتاج الأجنة فى الحيوانات النيات الكلمات الدالة: جودة البويضات، صبغة كريزيل الزرقاء الزاهية، جودة و اختبار الأجنة، النضج
\end{abstract}

